Author's name:

Pankaj R. Kaushik

Masters Student

Griffith School of Environment, Griffith University (Nathan Campus),

170 Kessels Rd, Nathan QLD 4111, Australia

E-mail: pankajram.kaushik@griffithun.edu.au

Co-author's name:

Dr Sunil Herat

Senior Lecturer in Environmental Engineering (Waste Management)

Griffith School of Engineering, Griffith University, Nathan Campus

170 Kessels Rd, Nathan QLD 4111, Australia

E-mail: s.herat@griffith.edu.au

Biographical statements:

Pankaj R. Kaushik is post graduate student of Environment studies in Griffith University, Brisbane Australia. He completed his undergraduate degree in Applied Geology from Kurukshetra University and State University, New York, US. Since graduation he has worked on surface water and ground water fields and helped to mitigate the groundwater contamination in New Delhi area. He has also worked on climate change impact on farmers and wheat crop with Indian Institute of Technology, New Delhi and helped farmers to save their crops from the natural disasters.

Dr. Sunil Herat is a Senior Lecturer in Environmental Engineering (Waste Management), School of Engineering and Built Environment, Griffith University, Australia. 


\title{
Current state of E-Waste Management in India
}

\begin{abstract}
Electronic Waste, or E-Waste in common parlance, is increasingly becoming a cause of concern in developing countries like India, due to environmental and human health hazards associated with it. Ironically, constituents of e-waste can be valuable, at the same time being toxic. The practices involved in managing and treating the electronic waste in India have limitations that need to be identified and resolved. The waste management can be properly executed if there are proper collection and disposing methods adopted. This can be possible only if there is proper awareness related to the ill-effects of e-waste among common people. This paper highlights the status of e-waste in India and the various techniques used for recycling and their limitations. The indicators assessing e-waste can be utilized as basic parameters for analysis in any nation. The valuable constituents present in e-waste can be used in creating business opportunities if properly treated and recycled.
\end{abstract}

\section{Keywords}

e-waste, management, recycling, business opportunities

\section{Introduction}

Electronic waste (also referred to as e-waste) or the waste from electrical and electronic equipment (WEEE) (Kahhat et.al, 2008), mainly consists of equipment used in data processing, communication, entertainment and businesses (Liu, Tanaka and Matsui, 2006). Ewaste is the electronic components after their usage and it is growing rapidly due to the increasing use of electronic products globally (Dwivedy and Mittal, 2010). The usage of electronic components is increasing due to decreased prices, growing usage of internet advancements in Information and Communications Technology (Nnorom and Osibanjo, 2008), (Osibanjo and Nnorom, 2007). More than half of the globally generated e-waste is exported for recycling mainly in the Asian countries like China and India due to the cheap labor (Ha et.al, 2009).

E-waste in India is not only increasing in amount but also in its toxicity, reason being the rapid growth in productivity and consumption in the electronics' sector (Dwivedy and Mittal, 2010). About 50,000 tons of e-waste is imported to India each year (Manomaivibool, 2009). The electronic and electrical components manufacturing industries are the largest growing sectors in India (Sepulveda et. al, 2010) producing 40,000 tons of e-waste itself every year (Sthiannopkao and Wong, 2013). The prediction says that India would generate approximately 52 million tons of e-waste by 2020 which constitutes about $40 \%$ of total ewaste generated all over the world (Vaidya, 2016). Electronic waste contains hazardous substances such as Cathode Ray Tube consisting of lead oxide, Lead, Mercury, Tin and other harmful metals which, if landfilled, can induce toxicity in groundwater and soil. E-waste is greatly hazardous for human as well as the environment if a proper management system is not followed for its treatment (Mundada, Kumar and Shekdar, 2004). Therefore, the 3R Principle needs to be implemented. The Rs in the 3R Principle stand for Reduce, Reuse and Recycle (Terazono et. al, 2006).

This paper also describes the management system and recycling methods for handling Ewaste in India and the challenges faced in the task, elaborating on the points on what exactly is e-waste, its generation, effects on environment and human health, the current adopted 
management system, recycling processes and challenges that the management system faces, etc. The indicators for analyzing e-waste management system is also reviewed that can be applied for any nation. Another important aspect, the business opportunities produced by ewaste in India, to create an employment generated platform is also discussed.

\section{E-waste}

Wastes from electronic and electrical components are categorized into ten groups as shown in the Table 1 given below:

Table 1: Categorization of E-waste

\begin{tabular}{|c|c|c|}
\hline S. No. & Category of Waste & Appliances \\
\hline 1. & $\begin{array}{l}\text { Large Household } \\
\text { Equipment }\end{array}$ & $\begin{array}{l}\text { Air conditioner, dishwasher, washing machine, } \\
\text { refrigerator and microwave oven, etc. }\end{array}$ \\
\hline 2. & $\begin{array}{l}\text { Small Household } \\
\text { Equipment }\end{array}$ & $\begin{array}{c}\text { Television, alarm clock, electric kettles, electric } \\
\text { chimneys, etc. }\end{array}$ \\
\hline 3. & $\begin{array}{l}\text { IT and } \\
\text { Telecommunication } \\
\text { Equipment }\end{array}$ & $\begin{array}{l}\text { Modems, landline telephones, mobile phones, } \\
\text { teleprinters and communication satellites. }\end{array}$ \\
\hline 4. & User Equipment & $\begin{array}{c}\text { Radio receivers, digital cameras, personal } \\
\text { computers, video recorders, MP3 player, CD and } \\
\text { DVD players }\end{array}$ \\
\hline 5. & Illumination Equipment & $\begin{array}{l}\text { Ballast lamp, LED and compact fluorescent } \\
\text { lamps }\end{array}$ \\
\hline 6. & $\begin{array}{l}\text { Electrical \& Electronic } \\
\text { Components }\end{array}$ & $\begin{array}{l}\text { Generators, transistors, motors, transformers, } \\
\text { wires, integrated circuits and batteries }\end{array}$ \\
\hline 7. & $\begin{array}{l}\text { Toys, Leisure \& Sports } \\
\text { Equipment }\end{array}$ & Batteries in cars, trains and airplanes, etc. \\
\hline 8. & Medical Apparatus & Thermometer and biotechnological apparatus \\
\hline 9. & $\begin{array}{l}\text { Monitoring \& Controlling } \\
\text { Apparatus }\end{array}$ & Relays, thermostat and microcontrollers \\
\hline 10. & Automatic dispenser & $\begin{array}{l}\text { Automatic water dispenser, automatic soap } \\
\text { dispenser and automatic spray dispenser, etc. }\end{array}$ \\
\hline
\end{tabular}

Source: Garlapati, (2016)

The different kinds of electronic or electrical devices and their projected lifespan that leads to generation of e-waste in future are shown in the Table 2 given below:

Table 2: Types of E-Waste and their Lifespan

\begin{tabular}{|c|c|c|c|}
\hline $\begin{array}{c}\text { S. } \\
\text { No. }\end{array}$ & $\begin{array}{c}\text { Electronic } \\
\text { Equipment }\end{array}$ & $\begin{array}{c}\text { Mass of the } \\
\text { Device (in kg) }\end{array}$ & $\begin{array}{c}\text { Estimated } \\
\text { Lifespan (in } \\
\text { years) }\end{array}$ \\
\hline 1. & Personal computer & 25 & 3 \\
\hline
\end{tabular}




\begin{tabular}{|c|c|c|c|}
\hline 2. & Fax machine & 3 & 5 \\
\hline 3. & High-fidelity systems & 10 & 10 \\
\hline 4. & Cell phone & 0.1 & 2 \\
\hline 5. & Electronic games & 3 & 5 \\
\hline 6. & Photocopier & 60 & 8 \\
\hline 7. & Radio & 2 & 10 \\
\hline 8. & Television & 30 & 5 \\
\hline 9. & Video recorder & 5 & 5 \\
\hline 10. & Air-conditioner & 55 & 12 \\
\hline 11. & Dish washer & 50 & 10 \\
\hline 12. & Electric cooker & 60 & 10 \\
\hline 13. & Food mixer & 1 & 5 \\
\hline 14. & Freezer & 35 & 10 \\
\hline 15. & Hair-dryer & 1 & 10 \\
\hline 16. & Iron & 1 & 10 \\
\hline 17. & Kettle & 1 & 3 \\
\hline 18. & Microwave & 15 & 7 \\
\hline 19. & Refrigerator & 35 & 10 \\
\hline 20. & Telephone & 1 & 5 \\
\hline 21. & Toaster & 1 & 5 \\
\hline 22. & Tumble dryer & 35 & 10 \\
\hline 23. & Vacuum cleaner & 10 & 10 \\
\hline
\end{tabular}

Source: Gaidajis, Angelakoglou \& Aktsoglou, (2010)

\section{Scenario of e-waste in India}

Some of the major electronic devices that are responsible for increasing e-waste in India are television, laptops, mobile phones and desktops. The forecast of the e-waste generated from these devices are shown in the Table 3 given below:

Table 3: Generation of e-waste every year (in metric tons)

\begin{tabular}{|c|c|c|c|c|c|c|c|}
\hline Devices & $\mathbf{2 0 1 4}$ & $\mathbf{2 0 1 5}$ & $\mathbf{2 0 1 6}$ & $\mathbf{2 0 1 7}$ & $\mathbf{2 0 1 8}$ & $\mathbf{2 0 1 9}$ & $\mathbf{2 0 2 0}$ \\
\hline $\begin{array}{c}\text { Desktop } \\
\text { PCs }\end{array}$ & 59558 & 66429 & 67102 & 49648.5 & 41699 & 35947 & 32511 \\
\hline Laptops & 12640 & 15248 & 20673 & 25280 & 32360 & 40367 & 50769 \\
\hline $\begin{array}{c}\text { Mobile } \\
\text { Phones }\end{array}$ & 22919 & 23101 & 28827.5 & 33475 & 36172.5 & 38870 & 41925 \\
\hline
\end{tabular}




\begin{tabular}{|c|c|c|c|c|c|c|c|}
\hline Televisions & 130200 & 145800 & 168000 & 184200 & 202770 & 221550 & 241500 \\
\hline $\begin{array}{c}\text { Total e- } \\
\text { Waste } \\
\text { generated } \\
\text { Every } \\
\text { Year }\end{array}$ & 225317 & 250578 & 284602.5 & 292613.5 & 313001.5 & 336734 & 366705 \\
\hline
\end{tabular}

Source: Ahmed, Panwar \& Sharma, (2014)

The states that contributes maximum of e-waste in India are Maharashtra, Tamil Nadu, Andhra Pradesh, Uttar Pradesh, West Bengal, Delhi, Karnataka, Gujarat, Madhya Pradesh and Punjab. The amount of e-waste produced by these states is described in the Table 4 and the major cities which are largest producer of e-waste are depicted in the Table 5 given below:

Table 4: States Generating E-Waste

\begin{tabular}{|c|c|c|c|}
\hline S. No. & State & $\begin{array}{c}\text { Generated E-Waste (in } \\
\text { tons) }\end{array}$ & Percentage \\
\hline $\mathbf{1 .}$ & Maharashtra & 20270.59 & 18.49 \\
\hline $\mathbf{2 .}$ & Tamil Nadu & 13486.24 & 12.30 \\
\hline $\mathbf{3 .}$ & Andhra Pradesh & 12780.33 & 11.66 \\
\hline $\mathbf{4 .}$ & Uttar Pradesh & 10381.11 & 9.47 \\
\hline $\mathbf{5 .}$ & West Bengal & 10059.36 & 9.18 \\
\hline $\mathbf{6 .}$ & Delhi & 9729.15 & 8.87 \\
\hline $\mathbf{7 .}$ & Karnataka & 9118.74 & 8.32 \\
\hline $\mathbf{8 .}$ & Gujarat & 8994.33 & 8.20 \\
\hline $\mathbf{9 .}$ & Madhya Pradesh & 7800.62 & 7.11 \\
\hline $\mathbf{1 0 .}$ & Punjab & 6958.46 & 6.35 \\
\hline
\end{tabular}

Source: Begum, (2013)

Table 5: Major E-Waste Producing Cities in India

\begin{tabular}{|l|l|l|}
\hline $\begin{array}{l}\text { S. } \\
\text { No. }\end{array}$ & City & $\begin{array}{l}\text { Generated E-Waste (in } \\
\text { metric tons per year) }\end{array}$ \\
\hline 1. & Mumbai & $1,20,000$ \\
\hline 2. & Delhi (NCR) & 98,000 \\
\hline 3. & Bangalore & 92,000 \\
\hline 4. & Chennai & 67,000 \\
\hline 5. & Kolkata & 55,000 \\
\hline 6. & Ahmedabad & 36,000 \\
\hline 7. & Hyderabad & 32,000 \\
\hline 8. & Pune & 26,000 \\
\hline
\end{tabular}

Source: Ghosal, (2016)

In India, $60 \%$ of the total generated e-waste is kept in warehouses and the remaining $40 \%$ is sent for recycling or recovering processes. A large amount of energy can be saved if the generated electronic waste is recycled properly. The recyclers collect the e-waste at a very low cost from the persons involved in gathering waste from the communities, and recycle metals such as copper, iron, aluminium and steel through primitive techniques. A large amount of pollutants are infused in the environment through these primitive techniques. The 
formal recyclers are registered by control pollution control board (CPCB) each year. Presently, 23 formal recyclers are registered who treat the generated e-waste in the country through formal techniques. These recyclers are given only a particular amount of e-waste to be treated (C. Vats \& Singh, 2014). India ranks fifth in the world in generating e-waste (Dutta, 2017). The number of formal recyclers registered in the states of country is shown in the Table 6 given below:

Table 6: Enrolled recyclers with the amount of e-waste allotted to them

\begin{tabular}{|c|c|c|c|}
\hline S. No. & States & $\begin{array}{c}\text { No. of } \\
\text { Registered } \\
\text { Recyclers }\end{array}$ & $\begin{array}{c}\text { Amount of E-Waste to be } \\
\text { Recycled }\end{array}$ \\
\hline $\mathbf{1 .}$ & Andhra Pradesh & 2 & 11,800 MTA \\
\hline $\mathbf{2 .}$ & Gujarat & 1 & 12,000 MTA \\
\hline $\mathbf{3 .}$ & Karnataka & 7 & $\begin{array}{c}3,140.6 \text { MTA and 120,000 } \\
\text { numbers cartridges }\end{array}$ \\
\hline $\mathbf{4 .}$ & Maharashtra & 3 & 8,060 MTA \\
\hline $\mathbf{5 .}$ & Haryana & 1 & 1,200 MTA \\
\hline $\mathbf{6 .}$ & Rajasthan & 1 & 450 MTA \\
\hline $\mathbf{7 .}$ & Tamil Nadu & 6 & 38,927 MTA \\
\hline $\mathbf{8 .}$ & Uttar Pradesh & 1 & 1,000 MTA \\
\hline $\mathbf{9 .}$ & Uttarakhand & 1 & 12,000 MTA \\
\hline
\end{tabular}

Source: C. Vats \& Singh, (2014)

\section{Environment and Human Health related Issues from E-Waste}

E-waste is severely harmful for environment and health as it contains toxic materials like lead and other metals. The Cathode Ray Tubes (CRT) present in Personal Computers and televisions have high concentration of lead that must be treated separately. The 5.015 million units of Personal Computers (PCs) and 21.1 million units of televisions (TVs) were sold in 2013 (Ahmed et al., 2014). The constituents of different kinds of CRT are shown in the Table 7 given below:

Table 7: Constituents of different types of CRT glass

\begin{tabular}{|c|c|c|c|}
\hline S. No. & Item & Constituents & Basic Properties \\
\hline 1. & Panel & $\begin{array}{c}\text { 0-4\% lead oxide } \\
\text { Alkaline/alkaline earth } \\
\text { aluminosilicate }\end{array}$ & $\begin{array}{c}\text { Optical quality glass, } \mathrm{x}-\mathrm{ray} \\
\text { attenuation, color and tint } \\
\text { control }\end{array}$ \\
\hline 2. & Funnel & $\begin{array}{c}22-28 \% \text { lead oxide } \\
\text { Alkaline/alkaline earth } \\
\text { aluminosilicate }\end{array}$ & $\begin{array}{l}\text { High x-ray resistance, } \\
\text { viscosity control }\end{array}$ \\
\hline 3. & Neck & $\begin{array}{c}30 \% \text { lead oxide } \\
\text { Alkaline/alkaline earth } \\
\text { aluminosilicate }\end{array}$ & $\begin{array}{l}\text { Thermal expansion match to } \\
\text { funnel composition, x-ray } \\
\text { absorption }\end{array}$ \\
\hline 4. & Stem & $\begin{array}{l}29 \% \text { lead oxide alkaline } \\
\text { aluminosilicate }\end{array}$ & $\begin{array}{l}\text { Expansion match to metal } \\
\text { wire feed throughs, x-ray } \\
\text { absorption }\end{array}$ \\
\hline
\end{tabular}




\begin{tabular}{|c|c|c|c|}
\hline 5. & Gun mount & $\begin{array}{c}\text { Potassium } \\
\text { aluminosilicate } \\
\text { sintering }\end{array}$ & Crystallization \\
\hline 6. & Frit & $\begin{array}{c}70-80 \% \text { lead oxide zinc } \\
\text { borate }\end{array}$ & Low temperature \\
\hline
\end{tabular}

Source: Nnorom and Osibanjo, (2008)

E-waste must be treated separately from other wastes. If it is treated along with the other household wastes such as food waste, bottles, cans and clothes, then it'll be harmful for environment as well as for human health (Ramchandra and Saira, 2004). It has a high level of hazardous effect on human and environment (Tsydenova and Bengtsson, 2011).

By considering the impacts of e-waste as given in the Table 8, the electronic products must be designed properly so as to prevent the environment from its hazardous effects (Bridgen, Labunska, Santillo and Allsopp, 2005). The various causes of generating e-waste in India and its negative impacts on the human health are summarized in the Table 8 given below:

Table 8: Sources of e-waste and its impact on human health

\begin{tabular}{|c|c|c|c|}
\hline $\begin{array}{l}\text { S. } \\
\text { No. }\end{array}$ & Sources of E-Waste & Elements & Health Issues \\
\hline 1. & $\begin{array}{l}\text { Solder in printed circuit boards, } \\
\text { Glass panels and Gaskets in } \\
\text { Computer Monitors }\end{array}$ & Lead & $\begin{array}{l}\text { Damage to Central } \\
\text { Nervous System, blood } \\
\text { and Kidneys. }\end{array}$ \\
\hline 2. & $\begin{array}{l}\text { Chip Resistors and } \\
\text { Semiconductors }\end{array}$ & Cadmium & $\begin{array}{l}\text { - Accumulates in the Liver } \\
\text { and Kidneys } \\
\text { - Causes Neural damage } \\
\text { - Teratogenic }\end{array}$ \\
\hline 3. & $\begin{array}{l}\text { Relays and switches, Printed } \\
\text { circuit boards }\end{array}$ & Mercury & $\begin{array}{l}\text { Respiratory and Skin } \\
\text { Disorders due to bio- } \\
\text { accumulation in fishes. }\end{array}$ \\
\hline 4. & $\begin{array}{l}\text { Corrosion protection of } \\
\text { untreated and galvanized steel } \\
\text { plates, hardener for steel } \\
\text { housings }\end{array}$ & Chromium & $\begin{array}{l}\text { - DNA damage } \\
\text { - Asthmatic Bronchitis }\end{array}$ \\
\hline 5. & Cabling and Computer housing & Plastics & $\begin{array}{l}\text { Burning produces dioxin } \\
\text { which causes damage to } \\
\text { immune system and } \\
\text { interfere with regulatory } \\
\text { hormones }\end{array}$ \\
\hline
\end{tabular}




\begin{tabular}{|c|c|c|c|}
\hline 6. & $\begin{array}{l}\text { Plastic housing of electronic } \\
\text { components and circuit boards }\end{array}$ & $\begin{array}{l}\text { Brominated } \\
\text { flame } \\
\text { retardants }\end{array}$ & $\begin{array}{l}\text { Disrupts the Endocrine } \\
\text { System functions }\end{array}$ \\
\hline 7. & $\begin{array}{c}\text { Front panel of Cathode Ray } \\
\text { Tubes }\end{array}$ & Barium & $\begin{array}{l}\text { - Short term exposure } \\
\text { causes damage to Heart, } \\
\text { Liver and Spleen }\end{array}$ \\
\hline 8. & Motherboard & Beryllium & $\begin{array}{l}\text { - Lung cancer } \\
\text { - } \quad \text { Skin diseases like warts } \\
\text { - Inhalation of fumes and } \\
\text { dust causes chronic } \\
\text { beryllium disease. }\end{array}$ \\
\hline
\end{tabular}

Source: Kush and Arora, (2013)

The various harmful constituents of e-waste that leads to the degradation of the environment and are also responsible for various health hazards in human beings are depicted in the Figure 1 given below:

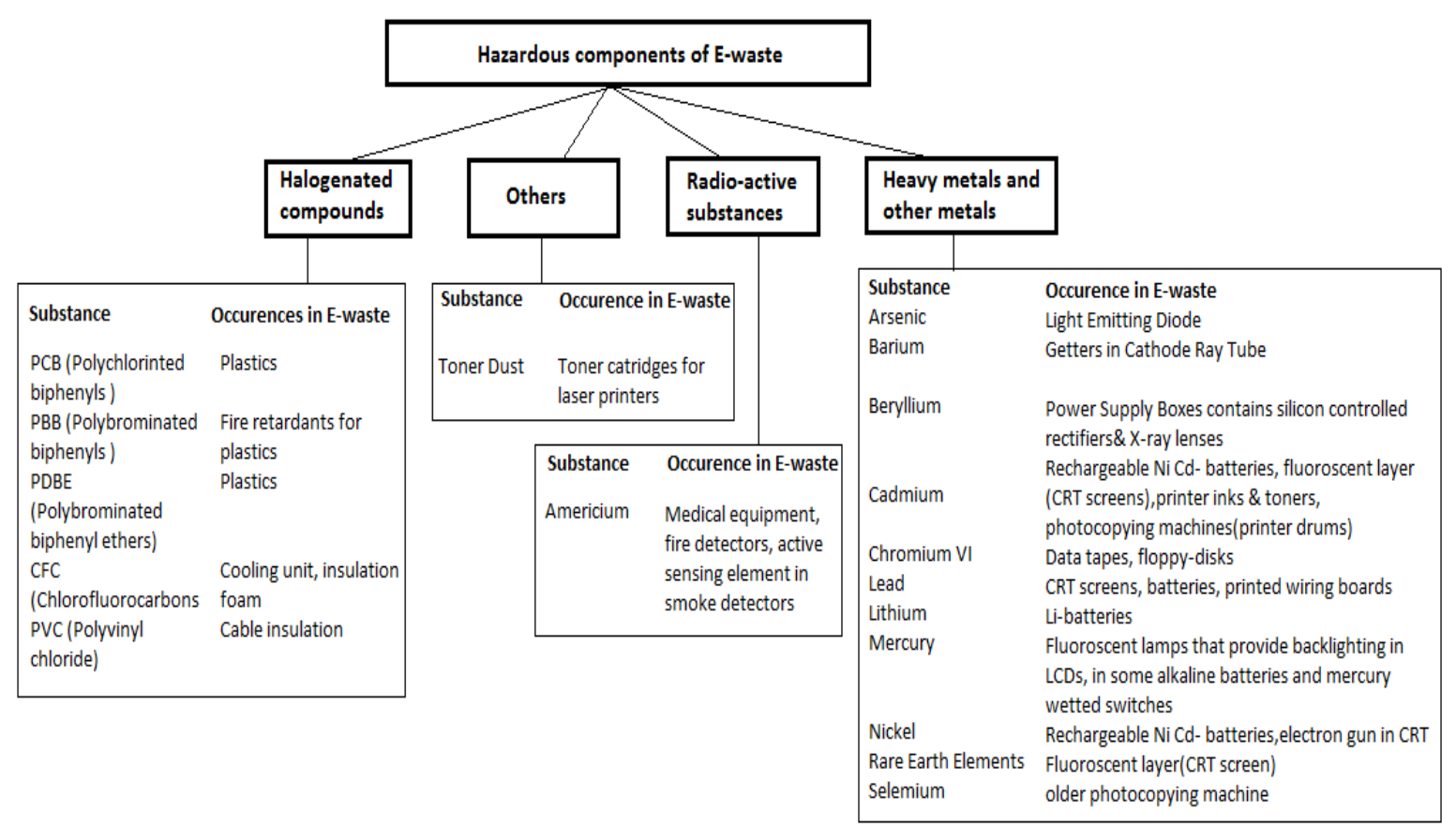

Figure 1: Harmful substances in E-waste

Source: Garlapati, (2016)

\section{Management of E-Waste in India}


E-waste is managed in industries by adopting four steps which are inventory management, production-process management, volume reduction and recovery and re-use. In the inventory management step, the components used in the manufacturing of electronic devices are controlled and thereby amount of waste produced can be decreased. The amount of e-waste can be decreased by following two ways - firstly, by creating review over purchasing of material and control processes and secondly, by an inventory tracking method. In the production-process management step, waste can be minimized by improving operating and maintenance processes, by changing materials used in manufacturing of product and by changing the existing procedure for developing the product. In the third step, that is the volume reduction, the techniques are applied to extract the harmful part of waste from nonharmful part and thereby the volume of the waste is minimized. Minimization of waste is achieved by segregating the waste at the source. Finally, in the recovery and reuse step, waste is recycled and the environment can be saved, as the recycling transfers the harmful substances into other products which are to be disposed (Sastry \& Ramachandra Murthy, 2012). The quantity of e-waste can be minimized to a large extent through recycling and reusing the products. Recycling and reusing of the material helps in conserving the energy and also in making the environment free from toxic substances (Joseph, 2007). The various elements of E-Waste Management System are shown in the Figure 2 given below:

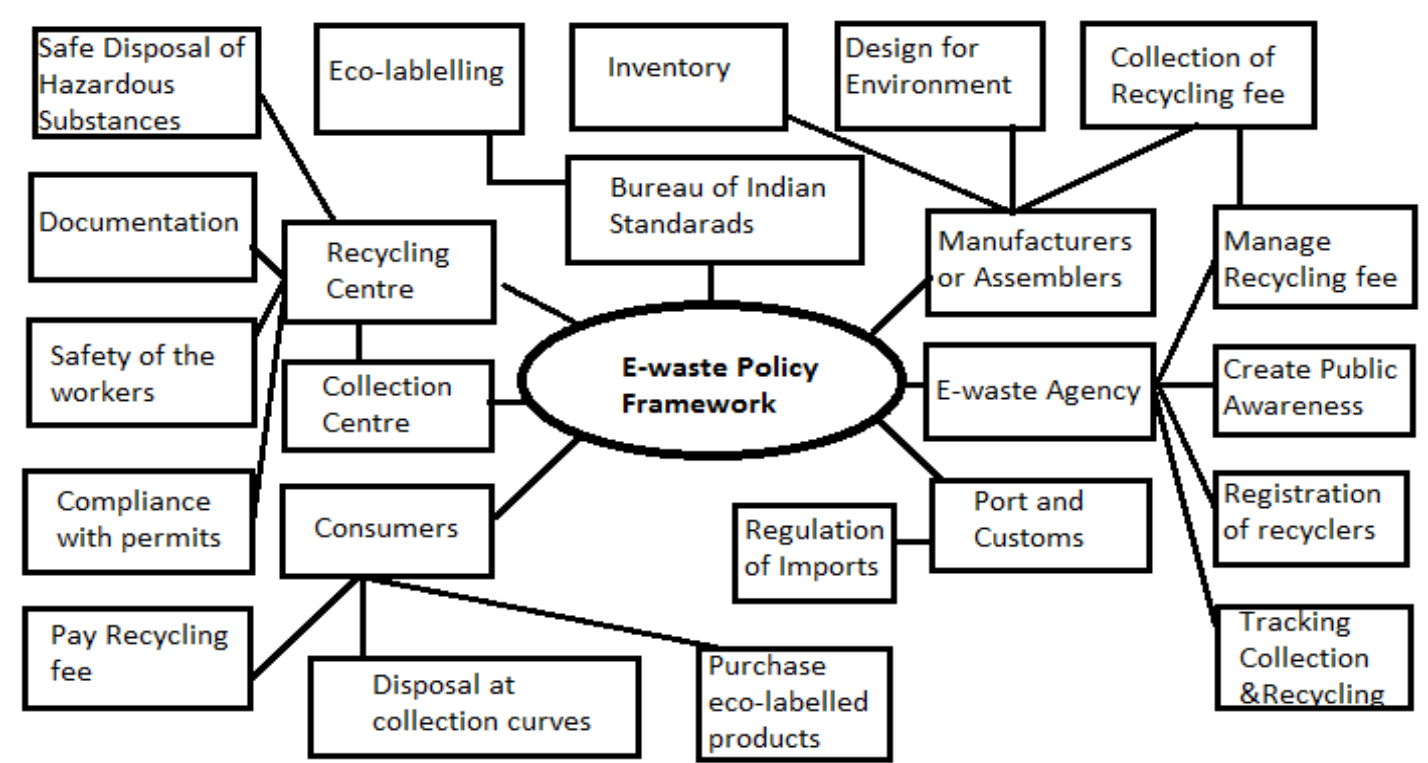

Figure 2: Components of E-Waste Management

Source: Joseph, (2007)

The various tools used for managing e-waste are Life Cycle Assessment (LCA), Material Flow Analysis (MFA), Multi Criteria Analysis (MCA) and Extended Producer Responsibility (EPR).

- Life Cycle Assessment (LCA) is a tool used for designing eco-friendly electronic equipment and for minimizing the problems created by e-waste. LCA is used for making decisions on managing computer-related waste in India.

- Material Flow Analysis (MFA) is a tool used to manage the flow of e-waste in environment and is used to analyze gold and copper flowing from recycling personal computer in India. 
- Multi-Criteria Analysis (MCA) is a tool used to find a suitable location for setting up recycling plants for e-waste.

- Extended Producer Responsibility (EPR) is a policy for ensuring responsibility of electronic components to the manufacturers even after their end of life (Kiddee, Naida and Wong, 2013).

Various tools used in India for managing e-waste are shown in the Table 9 given below:

Table 9: Tools to manage e-waste and their applications

\begin{tabular}{|c|c|c|c|}
\hline $\begin{array}{c}\text { S. } \\
\text { No. }\end{array}$ & Tool & Application & Aspects \\
\hline 1. & $\begin{array}{c}\text { Life Cycle } \\
\text { Assessment (LCA) }\end{array}$ & $\begin{array}{c}\text { Decision makers for managing } \\
\text { computer waste }\end{array}$ & $\begin{array}{c}\text { Environment and } \\
\text { economic }\end{array}$ \\
\hline 2. & $\begin{array}{c}\text { Material Flow } \\
\text { Analysis (MFA) }\end{array}$ & E-waste trade value chain & $\begin{array}{c}\text { Life span and } \\
\text { market supply }\end{array}$ \\
\hline 3. & $\begin{array}{c}\text { Material Flow } \\
\text { Analysis (MFA) }\end{array}$ & $\begin{array}{c}\text { The flow of personal computers and } \\
\text { pathways of recycling }\end{array}$ & Economic value \\
\hline
\end{tabular}

Source: Kiddee, Naida and Wong, (2013)

The present management system for handling and treating e-waste in India is shown in Figure 3 , given below:

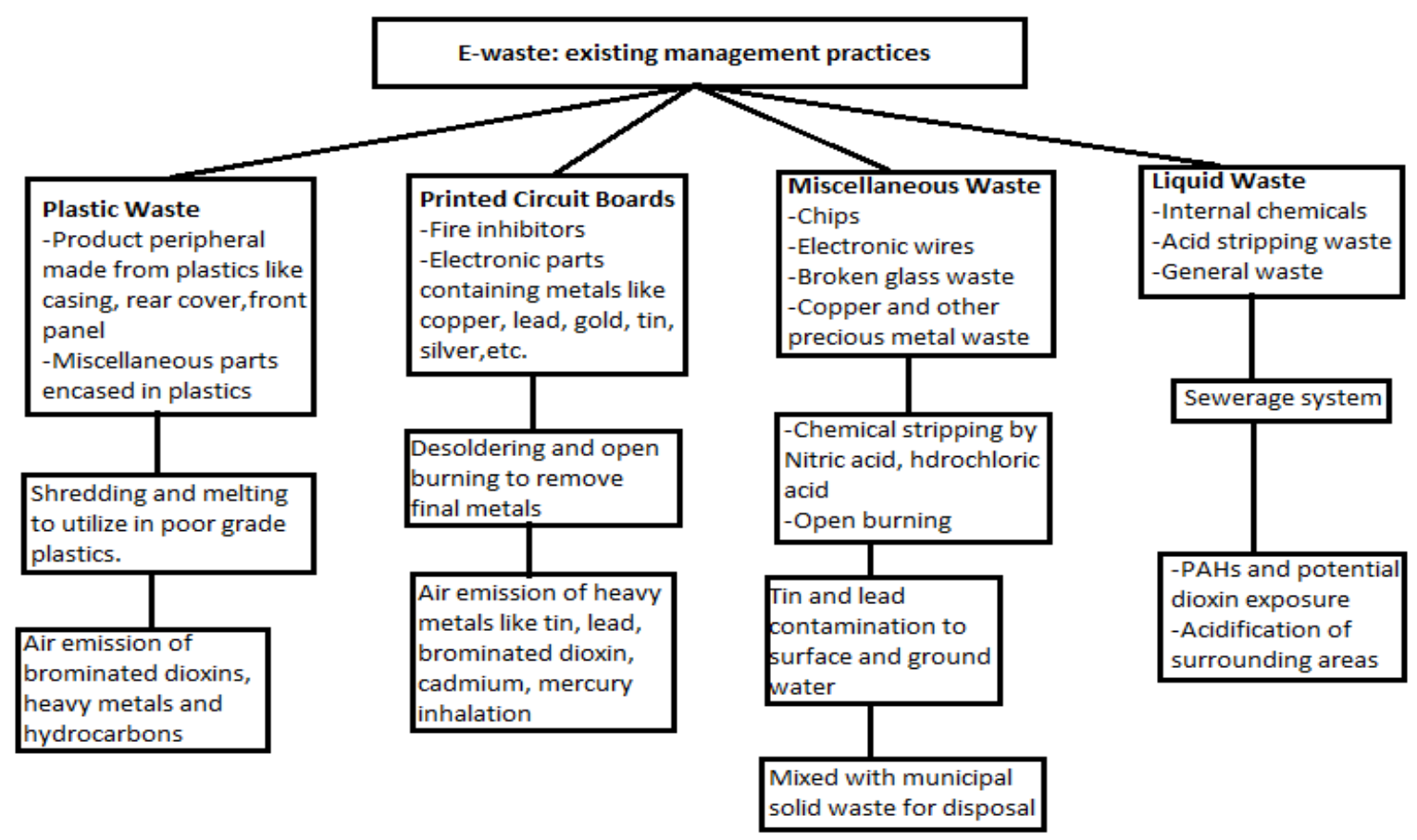

Figure 3: Existing management processes of e-waste in India

Source: Mundada, Kumar and Shekdar, (2004) 
The various initiatives taken by the Government of India for managing e-waste are given below:

- E-Parisaraa - This is the first scientific plant established for recycling e-waste to minimize the e-waste pollutants and also recover metals.

- Earth Sense Recycling Private Limited - This Company was established for managing bio-medical waste in 2000 and now it handles every kind of waste management, including e-waste.

- Trishyiraya Recycling India Pvt. Ltd. - This Company has been certified by Government of India and it recycles the e-waste.

- Plug-into E-cycling - Here, e-cycling refers to recycling and recovering. This helps to reduce emissions of greenhouse gases in the atmosphere.

- Installations of e-Bins in Bangalore City - E-bins are installed to create awareness among the dwellers regarding e-waste (Jhariya, Sahu \& Raj, 2014).

The various factors responsible for creating problems in managing e-waste properly are generation of e-waste in large amount; not having a proper law for banning children involved in different processes of e-waste treatment; ill-effects of e-waste on human beings and environment; lack of awareness among people; e-waste coming from other countries for recycling in India; and large investment in recycling plants of e-waste (Kumar, 2016). EWaste Management Practices in India face many challenges which must be analyzed as shown in Figure 4 given below:

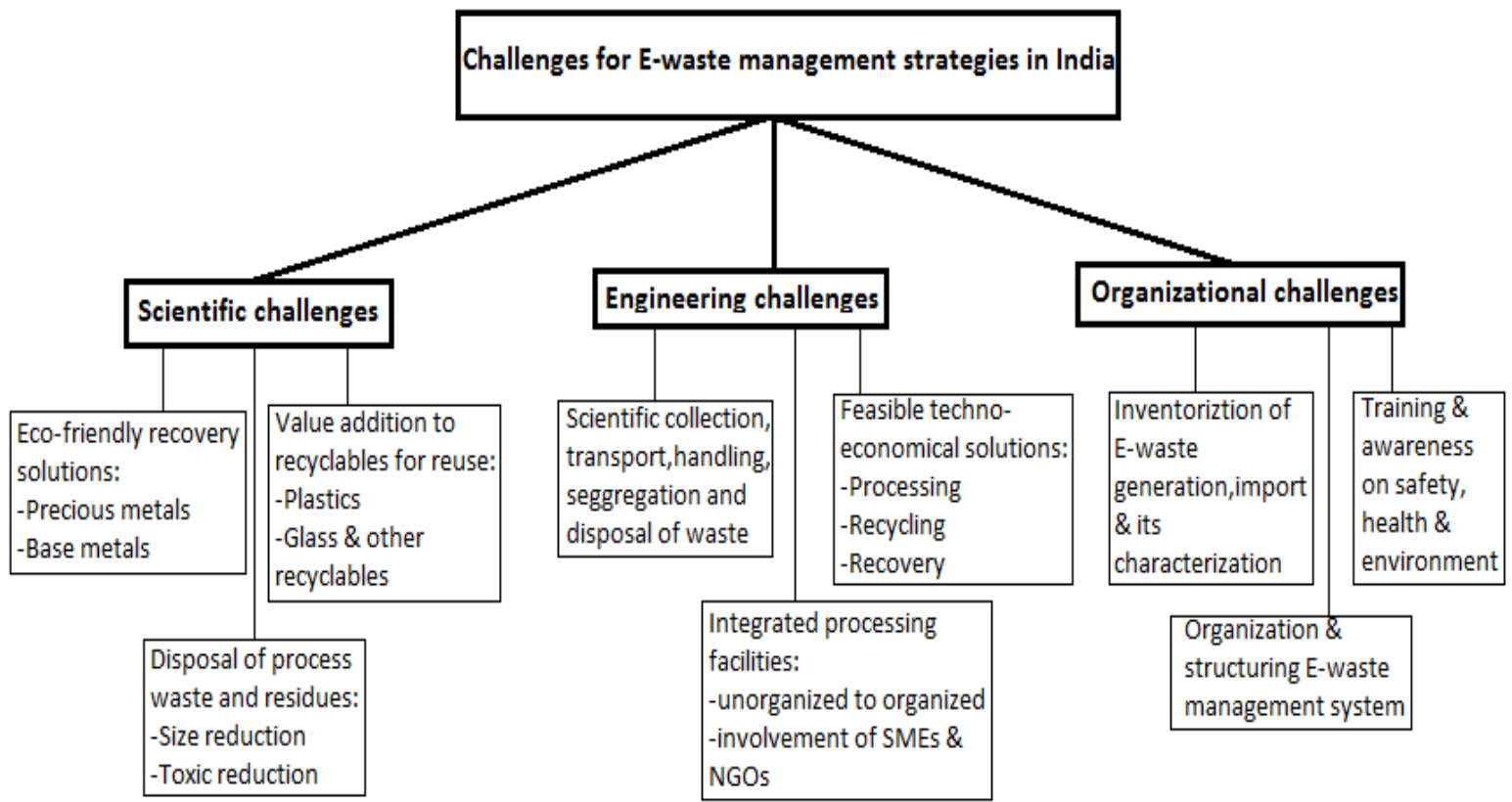

Figure 4: Challenges Faced by E-waste Management Strategies in India

Source: Wath, Dutt and Chakrabarti, (2010) 


\section{Recycling methods of e-waste in India}

The recycling methods used to recycle the waste generated from printed circuit boards are pyrolysis method, hydrometallurgical method, mechanical recycling, air classification method, bio metallurgical method and magnetic separation method. In pyrolysis method, the printed circuit boards are placed at a very high temperature so that solder is melted and this process leaves a blackish material which yields metal-like copper by following leaching process. In the hydrometallurgical method, the metal constituents are dissolved in strong acids and the metals are recovered. In bio-metallurgical recycling, the metals are recovered by using bioleaching process. After recycling of waste PCB in which metals are recovered, non-metallic portion is left. This non-metallic portion is very light and can be used as filler materials (Gupta, Modi, Saini \& Agarwal, 2014). The different levels in recycling of e-waste are primary level, secondary level and tertiary level. The procedures followed at each level and the output of each level is shown in the Table 10 given in the next page.

Table 10: Different Levels in the Recycling of E-Waste

\begin{tabular}{|c|c|c|c|c|c|}
\hline $\begin{array}{c}\text { S. } \\
\text { N } \\
\text { o. }\end{array}$ & $\begin{array}{c}\text { Level of } \\
\text { Treatme } \\
\text { nt }\end{array}$ & Processes & Output & $\begin{array}{c}\text { Role of } \\
\text { Technology }\end{array}$ & $\begin{array}{c}\text { Main } \\
\text { Technologies }\end{array}$ \\
\hline 1. & Primary & $\begin{array}{c}\text { Waste is } \\
\text { Degregated into } \\
\text { decontaminated } \\
\text { waste, like } \\
\text { nlastic, printed } \\
\text { disassmantling, } \\
\text { sorting and } \\
\text { circuit board, and } \\
\text { harmful waste } \\
\text { like batteries, } \\
\text { mercury switches, } \\
\text { etc. }\end{array}$ & low & $\begin{array}{c}\text { Typically a manual } \\
\text { process }\end{array}$ \\
\hline
\end{tabular}




\begin{tabular}{|c|c|c|c|c|c|}
\hline 2. & $\begin{array}{c}\text { Secondar } \\
\mathrm{y}\end{array}$ & $\begin{array}{l}\text { Hammering, } \\
\text { shredding, } \\
\text { separation of } \\
\text { waste streams } \\
\text { and CRT } \\
\text { treatment }\end{array}$ & $\begin{array}{l}\text { The material } \\
\text { output can be } \\
\text { categorized into } \\
\text { glass, plastic, } \\
\text { contaminated } \\
\text { plastic stream, } \\
\text { ferrous metal } \\
\text { stream and non- } \\
\text { ferrous metal } \\
\text { stream }\end{array}$ & Medium & $\begin{array}{l}\text { Electromagnetic, } \\
\text { eddy current, } \\
\text { density separation, } \\
\text { and variable vortex } \\
\text { technology } \\
\text { Splitting } \\
\text { technology in CRT } \\
\text { treatment like Ni- } \\
\text { chrome wire } \\
\text { cutting, thermal } \\
\text { shock, laser cutting } \\
\text { and diamond wire } \\
\text { method }\end{array}$ \\
\hline 3. & Tertiary & $\begin{array}{l}\text { Pulverization } \\
\text { and advanced } \\
\text { separation, } \\
\text { leaching for } \\
\text { metal recovery } \\
\text { and energy } \\
\text { recovery }\end{array}$ & $\begin{array}{l}\text { Plastic, ferrous } \\
\text { metal, precious } \\
\text { group metals like } \\
\text { gold and platinum } \\
\text { and other metals } \\
\text { like aluminum } \\
\text { and lead and } \\
\text { energy recovered } \\
\text { from } \\
\text { contaminated } \\
\text { plastic stream }\end{array}$ & High & $\begin{array}{l}\text { Plastic separation } \\
\text { using skin } \\
\text { floatation } \\
\text { technology and } \\
\text { electrostatic } \\
\text { separation } \\
\text { PGM recovery } \\
\text { using smelting, } \\
\text { electrochemical } \\
\text { process and } \\
\text { Haber's process }\end{array}$ \\
\hline & & & & & \\
\hline
\end{tabular}

Source: Frost \& Sullivan, (2013)

The recovery of materials from recycling of e-waste is shown in Figure 5 given below:

\section{Sales}

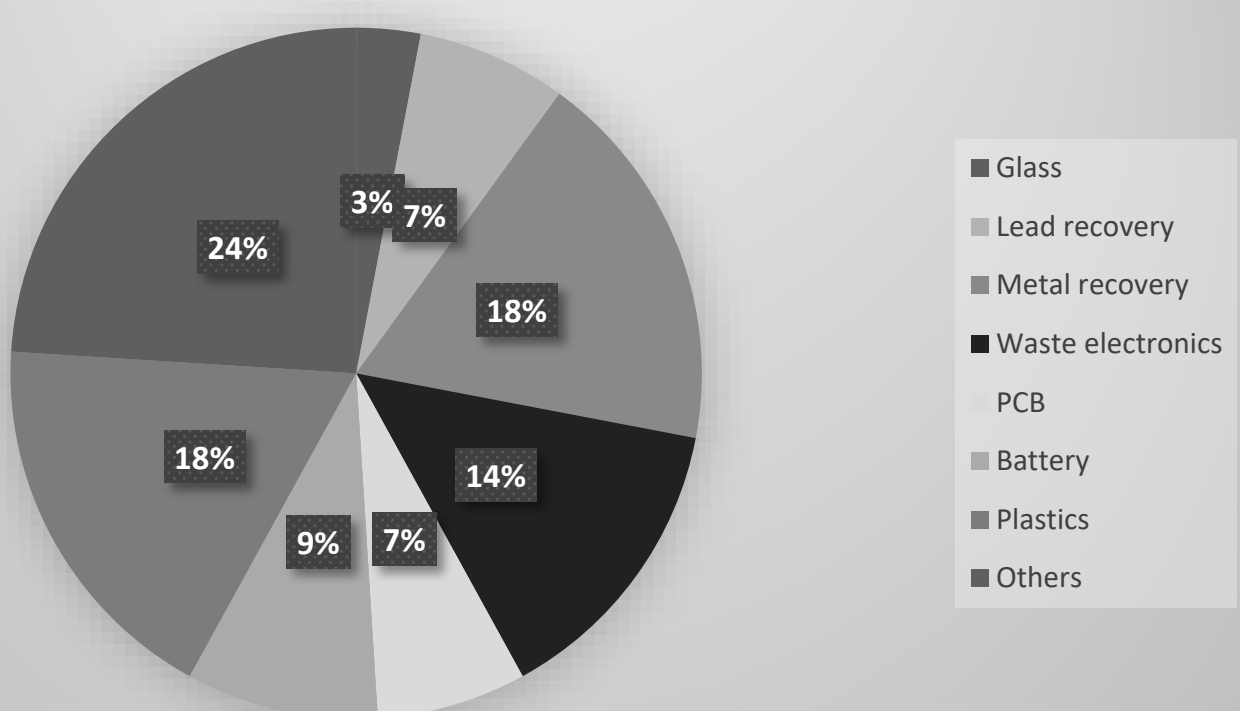


Figure 5: Recovered Materials from Recycling Processes

Source: Dey, (2014)

\section{Indicator Model for E-Waste Management System}

The indicator model used to assess the e-waste management system for a country is a threepointer scale. The model is used to analyze the management of e-waste for a nation and there are three aspects involved in modeling the indicator which is summarized in the given below Table 11:

Table 11: Aspects of Indicator Model to Assess E-Waste Management System

\begin{tabular}{|c|c|c|c|}
\hline $\begin{array}{l}\text { S. } \\
\text { No. }\end{array}$ & Aspects & Criterion & Indicator \\
\hline 1. & $\begin{array}{c}\text { Structural } \\
\text { Framework }\end{array}$ & $\begin{array}{l}\text { Policies and } \\
\text { Legislation } \\
\text { Economy }\end{array}$ & $\begin{array}{l}\text { Ratification of Basel Convention } \\
\text { Status of National Waste Legislation } \\
\text { Status of National E-Waste Legislation } \\
\text { Corruption Perception Index } \\
\text { Capital Cost } \\
\text { Secondary Raw Material Market } \\
\text { Civil and Political Liberties } \\
\text { NGO Activities } \\
\text { Recycling Culture } \\
\text { Environmental Awareness in Society } \\
\text { Knowledge in E-Waste Recycling } \\
\text { Technologies } \\
\text { Research in Recycling Technologies }\end{array}$ \\
\hline 2. & $\begin{array}{c}\text { Recycling } \\
\text { System }\end{array}$ & $\begin{array}{l}\text { Technologies } \\
\text { Financial flow }\end{array}$ & $\begin{array}{l}\text { E-waste generation per capita } \\
\text { Closed loop recycling management } \\
\text { Efficiency of material recovery } \\
\text { Quality of recovered material } \\
\text { Financial coverage } \\
\text { Externalities coverage }\end{array}$ \\
\hline
\end{tabular}




\begin{tabular}{|c|c|c|l|}
\hline Impacts & Environment & $\begin{array}{l}\text { Final disposal of e-waste in unsafe landfills } \\
\text { Emissions of harmful materials } \\
\text { Human health } \\
\text { Health and safety implementations at } \\
\text { workplace } \\
\text { Exposure of neighboring population to } \\
\text { harmful substances }\end{array}$ \\
Labor & $\begin{array}{l}\text { Number of jobs generated } \\
\text { Income distribution }\end{array}$ \\
\hline
\end{tabular}

Source: Widmer et. al, (2005)

\section{Rules and Laws of E-Waste in India}

Basel Convention, by the United Nations, came into effect on May 5, 1992 that proposed an agreement between nations for controlling and managing hazardous materials across their boundaries. According to Basel Convention, recycling of wastes is a way of disposing the substances (Babu, Parande an Basha, 2007). The laws for preventing the environment and human health from e-waste in India are shown in Table 12 given below:

Table 12: Laws to protect from e-waste hazards

\begin{tabular}{|c|c|c|c|}
\hline $\begin{array}{c}\text { S. } \\
\text { No. }\end{array}$ & Laws & Content & Date \\
\hline 1. & $\begin{array}{l}\text { Environment (Protection) Act, } \\
1986 \text { (Amendment 1991) }\end{array}$ & $\begin{array}{l}\text { Empowers Central } \\
\text { Government to take } \\
\text { measures to protect } \\
\text { and improve } \\
\text { environment quality. }\end{array}$ & Effective from 1986 \\
\hline 2. & $\begin{array}{l}\text { Hazardous Waste Rules, } 2008 \\
\text { (Amendments 2009) }\end{array}$ & $\begin{array}{l}\text { Provides stipulations } \\
\text { on management, } \\
\text { disposal and } \\
\text { transboundary } \\
\text { movement of solid } \\
\text { waste of hazardous } \\
\text { nature. }\end{array}$ & Effective from 2008 \\
\hline 3. & $\begin{array}{l}\text { Batteries (Management and } \\
\text { Handling) Rules, } 2001\end{array}$ & $\begin{array}{l}\text { Responsibility for safe } \\
\text { disposal and recycling } \\
\text { of lead acid batteries }\end{array}$ & Effective from 2001 \\
\hline 4. & $\begin{array}{c}\text { National Environmental Tribunal } \\
\text { Act, } 1995\end{array}$ & $\begin{array}{c}\text { Provide for strict } \\
\text { liability for damage } \\
\text { arising out of } \\
\text { accidents caused from } \\
\text { handling of hazardous } \\
\text { substances. }\end{array}$ & Effective from 1995 \\
\hline
\end{tabular}




\begin{tabular}{|c|c|c|c|}
\hline 5. & $\begin{array}{c}\text { The Air (Prevention and Control of } \\
\text { Pollution) Act }\end{array}$ & $\begin{array}{c}\text { Provide for } \\
\text { prevention, control } \\
\text { and abatement of air } \\
\text { pollution in India }\end{array}$ & Effective from 1981 \\
\hline
\end{tabular}

Source: Wath, Vaidya, Dutt \& Chakrabarti, (2010)

E-waste (Management and Handling) Rules are there to manage and handle the e-waste at various steps while collecting or treating it. These rules were notified under Environment (Protection) Act in 2010 (Notification number: S.O. 1035) to reduce the e-waste impacts on environment. The salient characteristics in these rules are depicted in the given below Table 13

Table 13: E-Waste (Management and Handling) Rules

\begin{tabular}{|c|c|c|c|}
\hline $\begin{array}{c}\text { S. } \\
\text { No. }\end{array}$ & Chapters & Titles & Problems Addressed \\
\hline 1. & $\begin{array}{l}\text { Chapter 1: } \\
\text { Preliminary }\end{array}$ & $\begin{array}{ll}\text { - } & \text { Short Title and } \\
\text { Commencements } \\
\text { - } & \text { Definitions } \\
\text { - } & \text { Applications }\end{array}$ & $\begin{array}{l}\text { Includes the titles and } \\
\text { commencements of } \\
\text { the laws, applicable } \\
\text { stakeholders and } \\
\text { related definitions of } \\
\text { the terminology. }\end{array}$ \\
\hline 2. & $\begin{array}{c}\text { Chapter 2: } \\
\text { Responsibilities }\end{array}$ & $\begin{array}{ll}\text { - } & \text { Responsibilities of } \\
\text { Producers } \\
\text { - } \\
\text { Responsibilities of } \\
\text { Collection Centers } \\
\text { - } \\
\text { Responsibilities of } \\
\text { Consumers } \\
\text { - } \\
\text { Responsibilities of } \\
\text { Dismantler } \\
\text { - } \\
\text { Responsibilities of } \\
\text { Recycler }\end{array}$ & $\begin{array}{l}\text { Responsibilities of } \\
\text { do's and don'ts of } \\
\text { stakeholders are } \\
\text { discussed. }\end{array}$ \\
\hline 3. & $\begin{array}{c}\text { Chapter 3: } \\
\text { Procedure for } \\
\text { seeking } \\
\text { Authorization for } \\
\text { Handling E-Waste }\end{array}$ & $\begin{array}{l}\text { - Procedure for Grant of } \\
\text { Authorization } \\
\text { - } \\
\text { Power to Cancel an } \\
\text { Authorization } \\
\text { - Procedure for Grant of } \\
\text { Registration }\end{array}$ & 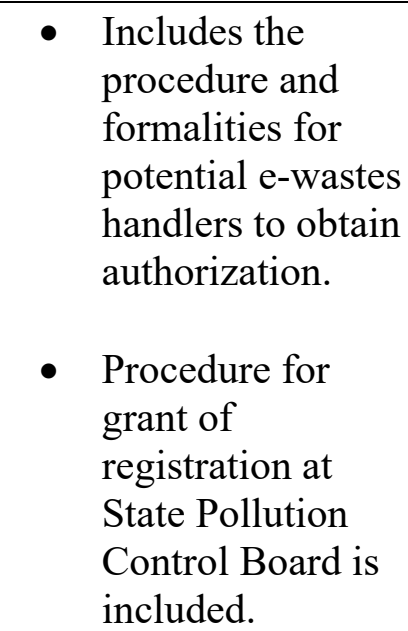 \\
\hline
\end{tabular}




\begin{tabular}{|c|c|c|c|}
\hline 4. & $\begin{array}{c}\text { Chapter 4: } \\
\text { Procedure for } \\
\text { Storing E-Waste }\end{array}$ & $\begin{array}{l}\text { Procedure for Storage } \\
\text { of E-Waste }\end{array}$ & $\begin{array}{l}\text { Maximum permissible } \\
\text { storage period of e- } \\
\text { waste with any } \\
\text { costumer is } 180 \text { days. }\end{array}$ \\
\hline 5. & $\begin{array}{l}\text { Chapter 5: } \\
\text { Reduction in Use of } \\
\text { Harmful Substances } \\
\text { in Manufacturing of } \\
\text { Electrical and } \\
\text { Electronic Devices }\end{array}$ & $\begin{array}{l}\text { Reduction in use of } \\
\text { harmful substances in } \\
\text { manufacturing of } \\
\text { electrical and } \\
\text { electronic devices }\end{array}$ & $\begin{array}{l}\text { Advises the } \\
\text { manufacturers to } \\
\text { reduce harmful } \\
\text { substances in } \\
\text { electronic and } \\
\text { electrical devices. The } \\
\text { maximum permissible } \\
\text { limit of lead, mercury, } \\
\text { calcium and other } \\
\text { elements are included. }\end{array}$ \\
\hline 6. & $\begin{array}{l}\text { Chapter 6: } \\
\text { Miscellaneous }\end{array}$ & 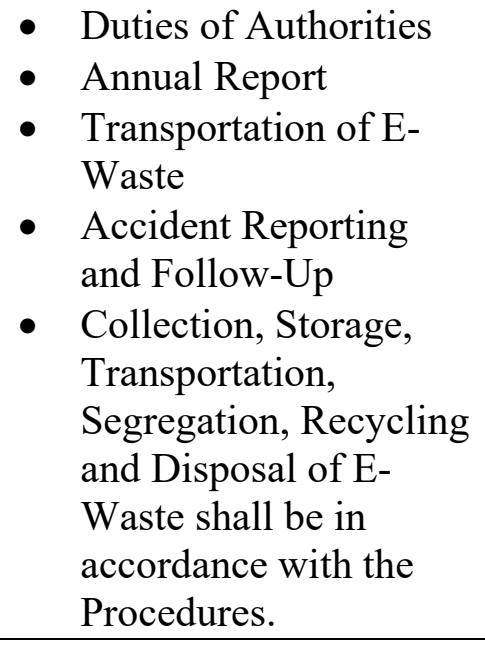 & $\begin{array}{l}\text { Includes the duties of } \\
\text { authorities, \& norms } \\
\text { of collection, storage, } \\
\text { transportation, and } \\
\text { disposal of e-waste, } \\
\text { duties of authorities, } \\
\text { etc. as well as } \\
\text { reporting of e-waste. }\end{array}$ \\
\hline
\end{tabular}

Source: Chatterjee, (2011)

\section{Business Opportunities From E-Waste}

The various sectors involved in generating e-waste are manufacturers, imports, information technology industries, educational institutes, individual households, traders and recyclers (Borthakur \& Sinha, 2013). The route of e-waste in management system is shown in Figure 6 given below: 


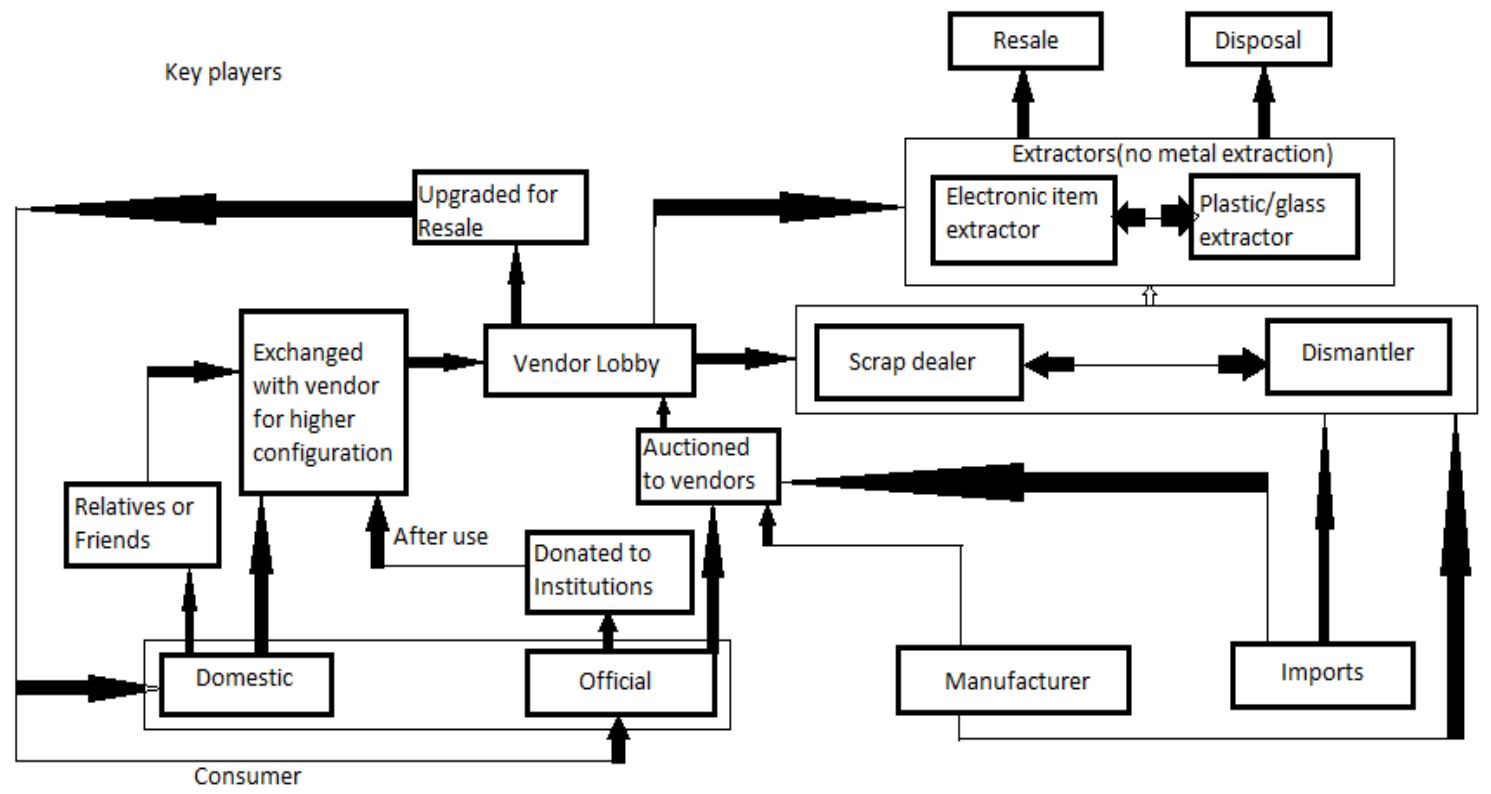

Figure 6: E-Waste Flow

Source: Wath, Vaidya, Dutt \& Chakrabarti, (2010)

In spite of the hazardous nature and effects of e-waste, one advantage of it is that it contains valuable metals such as gold, silver and copper. These metals can be brought back by adopting proper recycling methods. This presence of valuable metals in e-waste has made its recycling a platform for business in developing countries like India. The recycling processes of e-waste have high potential for employment in India (Khetriwal, Kraeuchi and Schwaninger, 2005).

\section{Conclusion}

E-waste is increasing at a rapid rate in India due to many reasons like growth in the electronics sector in the country and globalization that has increased the import of electronic items in the country. The electronic waste is greatly harmful for the ecosystem that includes humans, animals and environment. The toxic substances present in e-waste can cause serious damage to human health and other living organisms in the ecosystem.

Even though management systems and strategies exist to handle the task of safe disposition of the e-waste, still there are various challenges faced by the system for their successful implementation. There are various recycling processes have been discussed in this paper, which are not only helpful in removing toxic substances from the waste but also helpful in recovering valuable metals which might ultimately create substantive business opportunities in a developing nation like India.

The initiatives taken by the government such as rules and laws on e-waste described in section 8 in the direction of reducing harmful substances from the environment are commendable and useful to reduce the threat on human health and other environmental and ecological hazards caused by the wastes such as e-waste. 


\section{References}

i. Ahmed, S., Panwar, R.M. and Sharma, A., 2014. Forecasting e-waste amounts in India. International Journal of Engineering Research and General Science, 2(6), pp.2091-2730.

ii. Balakrishnan Ramesh Babu, Anand Kuber Parande and Chiya Ahmed Basha (2007). Electrical and electronic waste: a global environmental problem. Waste Management \& Research, 25(4), pp.307-318.

iii. Begum, K.J., 2013. Electronic waste (e-waste) management in India: A review. IOSR Journal of Humanities and Social Science (IOSR-JHSS), 10(4), pp.46-57.

iv. Borthakur, A., \& Sinha, K. (2013). Generation of electronic waste in India: Current scenario, dilemmas and stakeholders. African Journal Of Environmental Science And Technology, 7(9), 899-910.

v. Brigden, K., Labunska, I., Santillo, D. and Allsopp, M., 2005. Recycling of electronic wastes in China and India: workplace and environmental contamination. Greenpeace International, 55.

vi. C. Vats, M. and Singh, S. (2014). Status of E-Waste in India - A Review. International Journal of Innovative Research in Science, Engineering and Technology, 03(10), pp.16917-16931.

vii. Chatterjee, S. (2011). Electronic Waste and India. New Delhi. Retrieved from http://meity.gov.in/writereaddata/files/EWaste Sep11 892011.pdf

viii. Dey, S. (2014). E-waste recycling technology patents filed in india: an analysis. Journal of Intellectual Property Rights, 19, pp.315-324.

ix. Dutta, S. (2017). E-Waste: Tackling India's Next Big Waste Problem | Features. NDTVDettol Banega Swachh India.

x. Dwivedy, M. and Mittal, R. (2010). Estimation of future outflows of e-waste in India. Waste Management, 30(3), pp.483-491.

xi. Frost \& Sullivan (2013). Electronic Waste Management in India. Bangalore: Assocham, pp.1-18.

xii. Gaidajis, G., Angelakoglou, K. and Aktsoglou, D., 2010. E-waste: Environmental problems and current management. Journal of Engineering Science and Technology Review, 3(1), pp.193-199. 
xiii. Garlapati, V. (2016). E-waste in India and developed countries: Management, recycling, business and biotechnological initiatives. Renewable and Sustainable Energy Reviews, 54, pp.874-881.

xiv. Ghosal, S. (2016). India to produce 30 lakh metric tonnes of e-waste by 2018: Study. The Economic Times. Retrieved from https://economictimes.indiatimes.com/news/politicsand-nation/india-to-produce-30-lakh-metric-tonnes-of-e-waste-by-2018study/articleshow/51926570.cms

xv. Gupta, S., Modi, G., Saini, R., \& Agarwal, V. (2014). A review on various electronic waste recycling techniques and hazards due to its improper handling. International Refereed Journal Of Engineering And Science, 3(5), 5-17.

xvi. Ha, N., Agusa, T., Ramu, K., Tu, N., Murata, S., Bulbule, K., Parthasaraty, P., Takahashi, S., Subramanian, A. and Tanabe, S. (2009). Contamination by trace elements at e-waste recycling sites in Bangalore, India. Chemosphere, 76(1), pp.9-15.

xvii. Jhariya, M.K., Sahu, K.P. and Raj, A., 2014. E-waste, A New Challenge to the Environmentalists. Nature Environment and Pollution Technology, 13(2), p.333.

xviii. Joseph, K., 2007, October. Electronic waste management in India-issues and strategies. In Eleventh International Waste Management and Landfill Symposium, Sardinia.

xix. Kahhat, R., Kim, J., Xu, M., Allenby, B., Williams, E. and Zhang, P. (2008). Exploring ewaste management systems in the United States. Resources, Conservation and Recycling, 52(7), pp.955-964.

xx. Kiddee, P., Naidu, R. and Wong, M. (2013). Electronic waste management approaches: An overview. Waste Management, 33(5), pp.1237-1250.

xxi. Kumar, R. (2016). Current Scenario of e-waste management in India:issues and strategies. International Journal of Scientific and Research Publications, 6(1), pp.424430 .

xxii. Kush, A. and Arora, A. (2013). Proposed Solution of e-Waste Management. International Journal of Future Computer and Communication, pp.490-493.

xxiii. Liu, X., Tanaka, M. and Matsui, Y. (2006). Electrical and electronic waste management in China: progress and the barriers to overcome. Waste Management \& Research, 24(1), pp.92-101.

xxiv. Manomaivibool, P. (2009). Extended producer responsibility in a non-OECD context: The management of waste electrical and electronic equipment in India. Resources, Conservation and Recycling, 53(3), pp.136-144. 
xxv. Mundada, M., Kumar, S. and Shekdar, A. (2004). E-waste: a new challenge for waste management in India. International Journal of Environmental Studies, 61(3), pp.265-279.

xxvi. Nnorom, I. and Osibanjo, O. (2008). Electronic waste (e-waste): Material flows and management practices in Nigeria. Waste Management, 28(8), pp.1472-1479.

xxvii. Nnorom, I. and Osibanjo, O. (2008). Overview of electronic waste (e-waste) management practices and legislations, and their poor applications in the developing countries. Resources, Conservation and Recycling, 52(6), pp.843-858.

xxviii. Osibanjo, O. and Nnorom, I. (2007). The challenge of electronic waste (e-waste) management in developing countries. Waste Management \& Research, 25(6), pp.489501.

xxix. Ramachandra, T.V. and Saira, V.K., 2004. Environmentally sound options for e-wastes management. Envis Journal of Human Settlements, 5.

xxx. Sastry, S. and Ramachandra Murthy, C. (2012). Management of E-waste in the Present Scenario. International Journal of Engineering and Technology, 4(5), pp.543-547.

xxxi. Sepúlveda, A., Schluep, M., Renaud, F., Streicher, M., Kuehr, R., Hagelüken, C. and Gerecke, A. (2010). A review of the environmental fate and effects of hazardous substances released from electrical and electronic equipment during recycling: Examples from China and India. Environmental Impact Assessment Review, 30(1), pp.28-41.

xxxii. Sinha-Khetriwal, D., Kraeuchi, P. and Schwaninger, M. (2005). A comparison of electronic waste recycling in Switzerland and in India. Environmental Impact Assessment Review, 25(5), pp.492-504.

xxxiii. Sthiannopkao, S. and Wong, M. (2013). Handling e-waste in developed and developing countries: Initiatives, practices, and consequences. Science of The Total Environment, 463-464, pp.1147-1153.

xxxiv. Terazono, A., Murakami, S., Abe, N., Inanc, B., Moriguchi, Y., Sakai, S., Kojima, M., Yoshida, A., Li, J., Yang, J., Wong, M., Jain, A., Kim, I., Peralta, G., Lin, C., Mungcharoen, T. and Williams, E. (2006). Current status and research on E-waste issues in Asia. Journal of Material Cycles and Waste Management, 8(1), pp.1-12.

xxxv. Tsydenova, O. and Bengtsson, M. (2011). Chemical hazards associated with treatment of waste electrical and electronic equipment. Waste Management, 31(1), pp.45-58.

xxxvi. Vaidya (2016). Process and Control Management of Ever Increasing Generation of Ewaste. International Journal of Computer Applications, 151(5), pp.20-22. 
xxxvii. Wath, S., Dutt, P. and Chakrabarti, T. (2010). E-waste scenario in India, its management and implications. Environmental Monitoring and Assessment, 172(1-4), pp.249-262.

xxxviii. Wath, S., Vaidya, A., Dutt, P. and Chakrabarti, T. (2010). A roadmap for development of sustainable E-waste management system in India. Science of The Total Environment, 409(1), pp.19-32.

xxxix. Widmer, R., Oswald-Krapf, H., Sinha-Khetriwal, D., Schnellmann, M. and Böni, H. (2005). Global perspectives on e-waste. Environmental Impact Assessment Review, 25(5), pp.436-458. 